\title{
The Impact of Leadership Styles Used by the Academic Staff in the Jordanian Public Universities on Modifying Students' Behavior: A Field Study in the Northern Region of Jordan
}

\author{
Akif Lutfi Al-Khasawneh ${ }^{1} \&$ Sahar Moh'd Futa ${ }^{2}$ \\ ${ }^{1}$ Department of Finance and Administrative Sciences, AL-Huson University College, AL-Balqa' Applied \\ University, Irbid, Jordan \\ ${ }^{2}$ Faculty of Economics and Administrative Sciences/Department of Business Administration, Applied Science \\ University, Amman, Jordan \\ Correspondence: Akif Lutfi Al-Khasawneh, Department of Finance and Administrative Sciences, AL-Huson \\ University College, AL-Balqa' Applied University, P. O. Box 50, AL-Huson, 21510, Irbid, Jordan. Tel: \\ 96-277-543-2309. E-mail: akif_khasawneh@yahoo.com
}

Received: Steptember 13, $2012 \quad$ Accepted: November 12, $2012 \quad$ Online Published: December 4, 2012

doi:10.5539/ijbm.v8n1p1 URL: http://dx.doi.org/10.5539/ijbm.v8n1p1

\begin{abstract}
This study aims first to identify the leadership style which is used the most by the instructors in the Jordanian universities, and second to examine the impact of three leadership styles (Autocratic, Laissez-Faire and Democratic) on modifying student's behavior. The study population was the students studying at the faculty of economics and administrative sciences in 3 public universities, at the north region of Jordan, a random sample of students were selected. 600 questionnaires were distributed, 570 were analyzed. The results revealed that the academic staffs working at the surveyed universities are using the democratic style. The findings of the simple regression indicated that just the democratic leadership style had an impact on modifying students' behavior.
\end{abstract}

Keywords: leadership styles, academic staff, Jordanian Public Universities, student behavior modification

\section{Introduction}

People have been interested in leadership since they started coming together in groups to accomplish goals. But the researchers began to study leadership as an important process at the beginning of the twentieth century (Robbins \& Coulter, 2009). it was difficult to have one definition that can describe what leadership means, the term nowadays has different explanations that vary from one person to another and one from sector to another, regardless of the sector (politics, academic, social sciences, business etc.,) it must have that effect to influence individuals and their commitment in any organization (Timothy et al., 2011).

In the past the leader was the guy with answers. Today in successful companies it must be recognized that no leader can possibly have all the answers. The leader had to find ways to empower his followers, to challenge them, to provide them with resources they need and to hold them accountable. The leader becomes a coach, a teacher and a facilitator (Brown \& Harvey, 2006).

There is no one best leadership style that is always used, leaders usually use different styles in different situations. The literature has been interested in two basic leadership styles: the transactional and transformational, both of them are concerned with the relationship between leaders and their followers (Gadot \& Beeri, 2011). At the same time some researchers took into consideration the large known and simplest classification of leadership styles made by Kurt Lewin (1939) comprised by three categories: autocratic, democratic and laissez-faire (Raus \& Haita, 2011).

In academic institutions leaders may have a particularly unique set of skills required for effectiveness, as opposed to those in business, military, or government settings. This is partly due to the fact that colleges and universities have unique purposes in society, concerned with the knowledge of generation and the promotion of their learning and behavior (Kalargyrou et al., 2012). Recently universities are confronting new types of environmental challenges, new types of students; younger and more technology driven, globalization and diversity and the new mobility of ideas and people (Fullan \& Scott, 2009). Universities in particular have an 
important role to play in producing future knowledge workers and leaders. So that it is important to have a motivated, positively oriented, empowered and satisfied academic staff to be able to do their multiple roles (Coates et al., 2010).

Change is difficult for the members of any organization to accept therefore, reliance on the traditional leadership models is not the best method within which to enact sustained change. To stimulate and encourage positive change in this community, there must be opportunities for the academic staff and students to voice their views within an effective communication process (Randall, 2012). Leadership depends on exercising influence on behavior to induce compliance as a form of persuasion, as a power relationship, as an effect of interaction (Landis, 2011). The university years are considered the most important period of any student's life to develop his career life, his personality, and to build his leadership capabilities. Universities are the right place to form future generation of qualified leaders (Osiemo, 2012). Therefore, the main objective of this study is assessing the impact of leadership style of the academic staff on modifying the behavior of the Jordanian universities students.

\section{Problem of the Study}

The Problem addressed in this study is that universities in Jordan are confronting new patterns of student's behavior not compatible with the society culture, and society code of ethics, such as discrimination between different origins, violence, and the lack of positive social interaction between students themselves, with their teachers and with the universities administrators. As a result, these situations affect negatively universities atmosphere, student's level of performance, and student's safety, with a substantial amount of anxiety and stress to teachers and other students. In Jordan high education sector encounters a lot of challenges, it has the responsibility of facilitating education, learning and at the same time modification of students attitudes and behaviors to raise their citizenship awareness, and their duties towards the society they live in. While, empirical evidence exists in the literature confirms the positive impact of teacher's leadership style on modifying students' behavior. There are minimal empirical research studies concerning this subject in Jordan.

\section{Purposes of the Study}

This study has three purposes: first to identify which one of the following leadership styles (Autocratic, Laissez-faire and Democratic) is used the most by the academic staff in the public universities in Jordan from the students perception, the second purpose is to identify the impact of the leadership styles on modifying students' behavior, and their commitment to the universities code of ethics, culture, and universities rules and regulations. Third purpose aims to get benefit from the study's' findings and recommendations for the Jordanian universities, academics staff and administrators.

\section{Research Questions and Hypothesis}

- What is the leadership style that is mostly used by the academic staff in public universities in Jordan?

- Is there an impact of the Autocratic leadership style on modifying the students' behavior in the public Jordanian universities?

- Is there an impact of the Laissez-Faire leadership style on modifying the students' behavior in the public Jordanian universities?

- Is there an impact of the democratic leadership style on modifying the students' behavior in the public Jordanian universities?

The main hypothesis of the study is to examine the impact of the instructors' leadership style (Democratic, Autocratic \& Laissez faire) on modifying the behavior of the students studying in the public universities in Jordan.

\section{Methodology of the Study}

\subsection{Study Population \& Sample}

This study has been conducted in three public universities out of four working universities in the northern region in Jordan (Yrmouk, Al-albayet, Al balqa Applied represented by Alhuson University College and Ibrid girls University College). A random sample of 600 students was selected from the faculty of Economics and Administrative Sciences. 570 questionnaires were analyzed due to disqualification of the rest questionnaires for analysis.

\subsection{Tool of the Study}

Depending on the literature and previous studies, a questionnaire was developed for the purpose of collecting the required data; the tool has three parts: Part one aimed to collect data about sample characteristics. Part two 
concerned with the following leadership styles: Democratic leadership style questions from (1-7), Autocratic leadership style (8-15), laissez-faire questions from (16-20). The third part consisted of the questions from (21-32) \& concerned with the impact of leadership style on modifying students' behavior. Likert five degree scale was used, the values were between 1 : strongly disagree to 5 strongly agree.

\subsection{Tool's Validity and Reliability}

The researchers verified the validity of the study tool, by presenting it to a number of an academic staff in several Jordanian universities; to be reviewed, and the required amendments were done upon their notes. To test the internal consistency (reliability) of the questionnaire; cronbach alpha coefficient was calculated for the three leadership styles, and for their impact on modifying student's behavior.

It is obvious from the results displayed in table 1 that all the values of cronbach alpha were above the minimum accepted percentage (60\%) (Sekaran, 2004).

Table 1. Cronbach Alpha coefficient

\begin{tabular}{|c|c|}
\hline Variables & Cronbach's Alpha \\
\hline Question from 1-30 & 0.85 \\
\hline Democratic Style & 0.761 \\
\hline Autocratic style & 0.79 \\
\hline laissez-faire & 0.74 \\
\hline Leadership styles impact & 0.81 \\
\hline
\end{tabular}

\subsection{Statistical Methods and Tool}

For the purpose of describing the sample characteristics; percentages and frequencies were used. The Arithmetic mean and standard deviation were calculated to describe the sample trends towards study questions and Simple Regression was used for testing hypothesis and answering research questions.

\section{Theoretical Framework \& Literature Review}

Who leaders are? And what leadership is? The leader is someone who can influence others and at the same time has managerial authority; leadership is what leaders do (Robbins \& Coultar, 2009). It is a social process of influencing others to voluntary participate in achieving organizational goals (Buchanan \& Huczyynski, 2004); (Yukll, 2006); (Keitner \& kinicki, 2010). Leaders in this domain must have minimum specific characteristics, and principles to be able to inspire followers to achieve goals in high standards. (Valenti, 2010); besides the legitimate power leaders must have the knowledge and the ability of maintaining morale motivating followers (Dessler, 2012).

\subsection{Why Leadership is Important?}

According to Singh (2011) the effective leadership gets the others to behave as the mangers intends them to and at the same time satisfied their needs. The effective leader is able to communicate the organization vision, mission and objectives in a clear and lucid manner, enhancing creativity and innovation to provide a sustainable competitive advantage in today's global market to cope with the environmental factors changing fast.

Voegtlin et al. (2012) proposed that successful leader is more effective in building good and robust relations with stakeholders And can make the required organizational change especially in structure and culture with minimum resistance, Successful leaders are able to motivate, aspire, encourage followers in a way that results in more job satisfaction, commitment, loyalty and organizational citizenship behavior. So leadership has direct and indirect effect on organizational performance.

\subsection{Leadership Styles \& Theories}

Leadership style can be defined as the perceived behavior patterns that a person exhibits when attempting to influence the activities of others (Biggerstaff, 2012).

\subsubsection{Traits Theory}

Early research efforts devoted to leadership stressed what the leader was like rather than what he did. Many personality traits, social traits and physical characteristics can distinguish leaders from followers (Rue \& Byars, 
2007). This theory assumed that leaders are more intelligent than followers, able to initiate actions independently with high supervisory abilities, more creative, have high levels of adaptability and alertness \& self confidence.

Studies of the relationship between effective leadership and physical characteristics as height, weight and appearance provide contradictory results ((Ivancevich et al., 2008:414-416). At the same time researchers recognized that traits were not sufficient alone to identify effective leaders and the interactions between leaders and their group members had been ignored (Robins\& Coulter, 2009).

\subsubsection{Behavioral Theories}

These theories proposed that there are set of behaviors through which leaders are distinguished from non leaders . The attention switched from selecting leaders on their traits to the appropriate behavior patterns. Two projects the Michigan and Ohio studies underpinned the investigation of leadership style.

\subsubsection{University of Michigan Studies}

In 1940s and early 1950s Michigan research centre identified two leadership dimensions:

- Employee centered behavior focusing on employees needs and their relationship.

- Job centered behavior: focusing on getting the work done. (Buchanan \& Huczynski, 2004).

\subsubsection{Ohio State University Studies}

The work of Michigan University ran concurrently with the Bureau of Business Research at Ohio State university studies. A survey was developed called the Leader Behavior Description Questionnaire; it measured leadership styles in two dimensions:

- Consideration: support, mutual respect and trust and friendship between leaders and followers are the leadership behavioral indicators.

- Initiating Structure: the leader by which organized Tasks to be done, and how, determine the type of relationships, and the direction of communication channels (Dessler, 2004).

\subsubsection{University of Iowa Studies}

The research of Kurt Lewin (1939) and his group on leadership styles had resulted in the establishment of three leadership styles (the autocratic, laissez-faire \& democratic):

- The autocratic style: described a leader who dictated work methods, made unilateral decisions and limited employees participation (Robbins \& Coulter, 2009: 389) This leadership style is less creative, determining a permanent state of tension and discontent, resistance and decrease leaders interest of Subordinates (Raus $\&$ Haita, 2011).

- The Democratic Leadership It is a leadership style that involves people in decision-making process while the execution of the decision may be from the leader after facilitating consensus in the group. Implementing policies collectively and tasks are achieved from group discussions. In this kind of environment, criticism is allowed and praise is given the democratic leader encourages subordinates to identify problems and suggest solutions to overcome them (Amzat \& Ali, 2011). The findings of Tahseen (2012) study revealed that the democratic leadership style used by the school principal has no effect on teachers' job stress; while teachers were more stressed under the autocratic style. Bhatti et al. (2012) study found that the democratic leadership style had positively influence teachers' job satisfaction and ownership feeling in both private and public schools in Pakistan, where the teachers' were free to express their fears, propose and exchange their ideas and views. In the academic institutions the distributed leadership style is used interchangeably with the democratic. It depends on distributing authority at all levels of the organizations rather than it is centralized at the top (Kawar, 2012). The distributed style is able to enhance $\&$ facilitate learning by extension \& functional learning communities, and create high levels of commitment as a result of certain practices of such as trust, cooperation, participation in decision making and problem solving (Richmond \& Manokore, 2010). With more authority granted to teachers, empowerment and coaching both inside and outside classrooms (Firestone \& Martinez, 2007). This indicated that tasks are accomplished through a group of leaders working together in collaboration, role clarity and group cohesion (Humphreys, 2010; Saadi et al., 2009; Hulpia, et al., 2012).

- Laissez-Faire Leadership Style: It is defined as a style of Leadership where leaders refuse to make decisions, are not available when needed, and choose to take no responsibility for their lack of leadership ability (Biggerstaff, 2012) Laissez-faire leaders don't use their authority, avoid taking actions it is 
considered a passive and ineffective form of leadership (Bolda \& Nawaz, 2010). This style, favors the installation of a relaxed working atmosphere, it brings down morale and reduces efficiency of the group (Raus \& Haita, 2011).

\subsection{Leadership in the Twenty First Century}

Two related trends in leadership thinking became evident in the late twentieth century transactional and transformational leadership.

Transactional leader depends on reward and punishment to guarantee his followers acquiescence and compliance, he is ready to satisfy the followers' needs if they are able to accomplish the organizational goals (Buchanan \& Huczynski, 2004).

Transformational leadership (TL): is defined as a process that change and transforms people, whereby the followers feel respect, trust loyalty, and appreciation towards the leaders, and the followers are willing and motivated to do more than they expected.(Al-Hussein \& Elbeltagi, 2012). This style has positive impact on the goal directed behavior and enhances individual innovation and performance within organization (Ismail et al., 2010); (Kreitner \& Kinicke, 2010). With respect to transformational leadership style and educational leadership, transformational leaders ultimately affect change through a bottom-up approach; several studies investigated the impact of lewin 3 leadership styles and transactional and transformational styles on organizations performance and student achievements.

The study of Biggerstaff (2012) concludes that the transformational and democratic leadership styles have positive influence on student learning. The study of Lizzio et al. (2011) of the informal and formal teachers' leadership styles in 167 high public schools in Australia found that teachers' behavior and their democratic leadership style had an influence on students success, their citizenship feeling and their interaction with colleagues. These findings were consistent with Chu \& Kuo (2012) results which indicated that the leadership behaviors have an impact on the psychological contract in a Taiwan university. While the study of Chaudhry \& Javrd (2012) focused on Transformational, Transactional and Laissez faire leadership style and their impact on motivation in banking sector of Pakistan to identify which leadership style is good for motivating employees, it was found that Transformational leadership has positive, strong and significant association with the commitment and at the same time motivational level in respect of Laissez Faire was low. Bodla \& Nawaz (2010) conducted a comparative study between the public and the private institutes and universities n Pakistan concentrated on Transactional and Transformational leadership styles. The research results revealed that the transactional leadership style was used more in the public universities than the private, and this leadership style was more motivating than the transformational style in both sectors.

While the results of Amzat \& Ali (2011) showed that there was a positive significant relationship between Laissez faire leadership style and self efficacy of the academic staff in the studied university which has positive results of the student's achievements while there was no significant relationship between the democratic and autocratic leadership style and self efficacy of the academic staff in the studied university. Marie (2008) conducted a study in (17) Jordanian pharmaceutical manufacturing companies, found that there was a significant positive relationship between transformational leadership behavior, and human resource performance.

\section{Findings and Discussion}

\subsection{Descriptive Statistics}

The population of the study consisted of the faculty of economic and administrative sciences students in 3 public universities, at the north region of Jordan. 600 questionnaires were distributed, 570 were analyzed.

The results in table (2) show that $69 \%$ of the sample were males, $31 \%$ were females. $47 \%$ of them were in their third year (junior), while $21 \%$ in their first (freshman), $23 \%$ in the second year (sophomore). $9 \%$ were in their fourth year or more (senior). All of the respondents were between 19-23 years old.

Table 2. Characteristics of the sample

\begin{tabular}{cccc}
\hline Variables & Categories & Frequencies & Percentage \% \\
\hline \multirow{3}{*}{ Gender } & male & 393 & $69 \%$ \\
& Female & 177 & $31 \%$ \\
& Total & 570 & $100 \%$ \\
\hline
\end{tabular}




\begin{tabular}{cccc}
\hline & First year & 120 & $21 \%$ \\
Second & 131 & $23 \%$ \\
Studying Level & Third & 268 & $47 \%$ \\
& $4^{\text {th }}$ or more & 51 & $9 \%$ \\
& Total & 570 & $100 \%$ \\
\hline
\end{tabular}

The overall means and standard deviations of the responses are displayed in table 3 . It was found that all the means of (democratic leadership style) were above (3). These results indicated that the students believe in their instructors as (democratic leaders).The mean of enhancing creativity \& Innovation was the highest (4.01), with a standard deviation $=1.2$ followed by the overall mean of the friendly relationships between instructors and their students which was (3.80), with a standard deviation $=0.98$.

It is obvious from table 3 too that all the means of the Laissez-faire leadership style statements were less than 3 . And among the three styles it received the lowest mean scores which indicated that this leadership style is not applicable in the surveyed universities. While the results displayed in the table revealed that the autocratic leadership style is applied in a moderate degree. According to the respondents there is direct Control and tight follow up of rules and procedures in their universities with a mean of (3.15), and 0.97 standard deviation, and their instructors uses threat and punishment to improve students' performance with a mean $=(3.01)$ and 1.05 standard deviation. These practices were justified by the students; in order to guarantee the required order in the studying rooms. The mean score of statement 10 was (2.93). This result indicated that decisions are not taken by the instructors in isolation of students' participations and suggestions. Table 3 revealed the overall means and standard deviations of the three leadership styles impact on the students' behavior modification. It is obvious that the democratic style has the highest impact, with a mean of (4.032) and a standard deviation $=0.96$.followed by the autocratic style with a mean $=(2.71)$ and, 1.00 standard deviation. And the Laissez-Faire leadership style had the lowest impact with a mean $=(2.35)$ and 0.87 standard deviation.

Table 3. Descriptive statistics: means and standard deviations of responses

\begin{tabular}{|c|c|c|c|}
\hline \multicolumn{2}{|r|}{ Statement } & Mean & $\begin{array}{r}\text { Standard } \\
\text { deviation }\end{array}$ \\
\hline \multicolumn{4}{|c|}{ Democratic } \\
\hline 1. & Participation in decision making and problem solving & 3.12 & 0.87 \\
\hline 2. & Mutual respect, trust.. relationships & 3.80 & 0.98 \\
\hline 3. & Encourage and reward creativity and innovation & 4.09 & 1.2 \\
\hline 4. & Informal communication & 3.28 & 0.86 \\
\hline \multicolumn{4}{|c|}{ Laissez-Faire } \\
\hline 5. & Complete freedom in decision making and problem solving & 2.1 & 0.95 \\
\hline 6. & $\begin{array}{l}\text { Avoiding goal setting, involvement in decision making and problem } \\
\text { solving }\end{array}$ & 2.5 & 1.01 \\
\hline 7. & Lack of control directing, explaining actions to followers & 2.83 & 1.5 \\
\hline 8. & $\begin{array}{l}\text { followers are free to set their own goals and monitor their own } \\
\text { performance }\end{array}$ & 2.06 & 1.1 \\
\hline \multicolumn{4}{|c|}{ Autocratic Leadership } \\
\hline 9. & Direct Control and tight follow up of rules and procedures & 3.15 & 0.97 \\
\hline 10 & Centralized authority and decision making & 2.93 & 1.21 \\
\hline 11. & Formal communication & 2.86 & 0.79 \\
\hline 12. & Threat and punishment to improve performance & 3.01 & 1.05 \\
\hline \multicolumn{4}{|c|}{ Leadership Style Impact on Modifying Students' Behavior } \\
\hline & Democratic & 4.032 & 0.96 \\
\hline & Autocratic & 2.71 & 1.00 \\
\hline & Laissez-faire & 2.35 & 0.87 \\
\hline
\end{tabular}




\subsection{Hypothesis Testing}

For testing hypothesis simple linear regression was used, with the significance level of $\leq 0.05$. The critical value for acceptance and rejection was to reject the null hypothesis if $\mathrm{p}$-value was $\leq 0.05$.

Table 4 displays the (ANOVA), and the (Coefficients) results.

$\mathrm{Ho}_{1}$ : There is no impact of the Autocratic Leadership style on modifying students' behavior.

$H a_{1}$ : There is an impact of the Autocratic Leadership style on modifying students' behavior.

The results presented in table (4) show that the $F$ value was 2.577 with a $p$ value of 0.11 . And the value of $t$ was 1.605 with $\mathrm{p}$ value 0.11 , since $\mathrm{p}$-value was $>0.05$, we shall accept the null hypothesis. This means that the Autocratic leadership style has no effect on modifying students' behavior.

$\mathrm{Ho}_{2}$ : There is no impact of the Laissez Faire Leadership style on modifying students' behavior.

$\mathrm{Ha}_{2}$ : There is an impact of the Laissez Faire Leadership style on modifying students' behavior.

The results displayed in table (4) show that the $F$ value was 2.543 with a significant level $=0.112$, $t$ value was 1.595 with $p$ value of 0.112 this result revealed that Laissez-faire leadership style has no effect on modifying students' behavior.

$\mathrm{Ho}_{3}$ : There is no impact of the democratic leadership style on modifying students' behavior.

$\mathrm{Ha}_{3}$ : There is an impact of the democratic leadership style on modifying students' behavior.

The results show that the $F$ value was 53.129 with a $p$ value of 0.000 ; $t$ value was 7.289 with a 0.000 significant level; therefore $\mathrm{Ha}_{3}$ hypothesis is accepted. This indicated that the democratic leadership style has an impact on modifying students' behavior. The results of the correlations (R) between the 3 leadership styles (Autocratic, Laissez-Faire and Democratic were $(0.09,0.08,0.394)$ respectively, indicated that there is no significant relationship between the autocratic, and the Laissez-faire leadership styles and modifying students' behavior. But there was a positive significant association between the democratic style and modifying students' behavior. The coefficient of determination $\mathrm{R}^{2}=0.155$ therefore, about $15.5 \%$ of the variation in the students behavior is explained by the democratic leadership style. Table (4) displayed the coefficients (Beta) for the autocratic, Laissez-faire, and Democratic respectively (0.094, 0.093, and 0.394). These results indicated that the democratic leadership style had the highest effect, and it was the best motivator than the other styles to modify positively the behavior of the students.

Table 4. Simple regression results

\begin{tabular}{|c|c|c|c|c|c|}
\hline \multicolumn{6}{|c|}{ ANOVA } \\
\hline Autocratic & Model & Sum of Squares & Mean Square & $\mathrm{F}$ & Sig \\
\hline & Regression & 3.108 & 3.108 & 2.577 & 0.110 \\
\hline & Residual & 348.467 & 1.206 & & \\
\hline & Total & 351.575 & & & \\
\hline \multirow[t]{4}{*}{ Laissez faire } & Model & Sum of Squares & Mean Square & $\mathrm{F}$ & Sig \\
\hline & Regression & 1.561 & 1.561 & 2.543 & 0.112 \\
\hline & Residual & 177.410 & 0.614 & & \\
\hline & Total & 178.971 & & & \\
\hline \multirow[t]{5}{*}{ Democratic } & Model & Sum of Squares & Mean Square & $\mathrm{F}$ & Sig \\
\hline & Regression & 34.472 & 34.472 & 53.129 & 0.000 \\
\hline & Residual & 187.514 & 0.649 & & \\
\hline & Total & 221.986 & & & \\
\hline & & Coefficients & & & \\
\hline Autocratic & B & Std. Error & Beta & $\mathrm{T}$ & Sig. \\
\hline (Constant) & 2.704 & 0.337 & & 1.605 & 0.11 \\
\hline AUT & & & 0.094 & & \\
\hline
\end{tabular}




\begin{tabular}{cccccc} 
Laissez Faire & B & Std. Error & Beta & T & Sig. \\
(Constant) & 2.982 & 0.226 & & 1.595 & 0.112 \\
AUT & & & 0.093 & & \\
Democratic & B & Std. Error & Beta & T & Sig. \\
(Constant) & 2.044 & 0.185 & 0.394 & 7.289 & 0.000 \\
AUT & 0.330 & 0.045 & & & \\
\hline
\end{tabular}

\section{Conclusions and Recommendations}

The study aimed to examine the effect of three leadership styles (Autocratic, Laissez-Faire and Democratic) on modifying the behavior of university students in Jordan. The study was conducted in 3 public universities working at the northern region in Jordan. It has been found that just the democratic leadership style had a positive impact on modifying students' behavior. This result were consistent with (Kawar, 2012; Voegtlin et al. 2012; Amzat \& Ali, 2011; Firestone \& Martinez, 2007; Humphreys, 2010; Saadi et al., 2009; Hulpia et al., 2012; Lizzio et al., 2011). This confirmed that the Democratic style plays a vital role in teaching/ learning process. And can influence positively students behavior, knowledge, their commitment and citizenship behavior towards their university first and the society.

Also the findings of the study are consistent with Chu \& Kuo (2012), Bhatti et al. (2012) results which indicated that the democratic leadership behaviors have a positive impact on enhancing the psychological contract in a Taiwan university. While the findings of Tahseen (2012) study confirmed that the autrocratric leadership style used by principlas can result in more job stress to teachers than the democratic style.

The results implied that the other two styles have neither effect nor relationship with modifying students' behavior. With reference to the association between the autocratic style and Laissez-faire style $\mathrm{R}=0.09$, and 0.08 , at the same time $\mathrm{p}$ values for both styles were above $0.05=0.112$. the findings of the autocratic leadership style supported the results of (Raus \& Haita, 2011) \& (Biggerstaff, 2012:26) Which indicated that this leadership style is less creative, and caused a permanent state of tension and discontent, resistance and decrease leaders interest of Subordinates, at the same time.

The results of the Laissez-faire leaders style were consisted with (Bolda \& Nawaz, 2010), (Raus \& Haita, 2011), and (Chaudhry \& Javrd, 2012). Findings which considered this style as a passive and ineffective form of leadership, it brings down morale and reduces efficiency.

The findings of this study don't match Amzat \& Ali (2011) results which showed that the laissez-faire style just had the significant relationship with the self efficacy of the academic staff. in a Malaysian Islamic University. Depending on the results of the study the researchers recommended that democratic leadership style is the best style in dealing with young generation of students, this style is able to enhance \& facilitate learning through respect, trust, cooperation, involvement, and high level of obligation and commitment from teachers andstudents.

\section{Limitations and Future Research}

This study is considered a contribution in expressing the positive impact of the democratic leadership style on students' behavior. but it has several limitations; as it was conducted in the public high education sector, using small sample out of the large number of university students in Jordan, in addition to that the study was conducted in just one faculty, and in the north region of Jordan; it used 3 leadership styles: (Autocratic, Laissez faire, and Democratic).

For future research, the researchers suggest studying different leadership styles e.g. (transactional and transformational), in other public and private universities, with a large sample of both students and teachers.

\section{References}

Al-Husseini, S., \& Elbeltag, I. (2012). The Impact of Leadership Style and Knowledge Sharing on Innovation in Iraqi Higher Education Institutions. Copyright of Proceedings of the European Conference on Intellectual Capital is the property of Academic.

Amzat, I. H., \& Ali, A. K. (2011). The Relationship between the Leadership Styles of Heads of Departments and Academic Staff's Self-Efficacy in A selected Malaysian Islamic University. Interdisciplinary Journal of Contemporary Research in Business, 3(1), 940-964. 
Bhatti et al. (2012). The Impact of Autocratic and Democratic Leadership Style on Job Satisfaction. Interactional Business Research, 5(2), 192-201.

Biggerstaff, J. K. (2012). The Relationship between Teacher Perceptions of Elementary School Principal Leadership Style and Teacher Job Satisfaction. (Western Kentucky University), Dissertations Paper 22, Retrieved from http://digitalcommons.wku.edu/diss/22

Bodla, M. A., \& Nawaz, M. M. (2010). Comparative Study of Full Range Leadership Model Among Faculty Members in Public and Private Sector Higher Education, Institutes and Universities. International Journal of Business and Management, 5(4), 208-214.

Brown, D. R., \& Harvey, D. (2006). An Experimental Approach to Organizational Development (7 ${ }^{\text {th }}$ ed.). Upper Saddle River, New Jersey Pearson Prentice Hall.

Chaudhry, Abdul Qayyum, \& Javed Husnain. (2012). Impact of Transactional and Laissez Faire Leadership Style on Motivation. International Journal of Business and Social Science, 3, 258-270.

Chu, Hui-Chin, \& Kuo, Tsui-Yang. (2012). Exploring Faculty Psychological Contract through Leadership Style and Institutional Climate in a Higher Education Setting. International Journal of Business and Social Science, 3(4), 159-164.

Coatesa et al. (2010). Across the Great Divide: What Do Australian Academics Think of University Leadership? Advice from the CAP Survey. Journal of Higher Education Policy and Management, 32(4), 379-387. http://dx.doi.org/10.1080/1360080X.2010.491111

Dessler, G. (2004). Management: Principles and Practices for Tomorrow's Leaders ( ${ }^{\text {rd }}$ ed.). Boston, Pearson prentice Hall.

Dessler, G. (2012). Fundamentals of Human Resource Management ( $2^{\text {nd }}$ ed.). Boston, Pearson prentice Hall.

Firestone, W., \& Martinzen, C. (2007). Districts, Teacher Leaders, and Distributed Leadership: Changing Instructional Practice. Leadership and Policy in Schools, 6, 3-35. http://dx.doi.org/10.1080/15700760601091234

Fullan, M., \& Scott, G. (2009). Turnaround Leadership for Higher Education. San Francisco John Wiley \& Sons.

Gadot, E. V., \& Beeri, I. (2011). Change-Oriented Organizational Citizenship Behavior in Public Administration: The Power of Leadership and the Cost of Organizational Politics. The Journal of Public Administration Research, 22, 573-596. http://dx.doi.org/10.1093/jopart/mur036

Huczynsk, A., \& Buchannan, D. (2004). Organizational Behavior: an introductory Text (5 ${ }^{\text {th }}$ ed.). Prentice Hall, New York.

Hulpia et al. (2012). Dimensions of Distributed Leadership and the Impact on Teachers' Organizational Commitment: A Study in Secondary Education. Journal of Applied Social Psychology, 42(7), 1745-1784. http://dx.doi.org/10.1111/j.1559-1816.2012.00917.x

Humphreys, E. (2010). Distributed Leadership and its Impact on Teaching and Learning. PhD Thesis, National University of Ireland. Retrieved from hattp://eprints.nuim.ie/2041/. Cited on 20/8/2012

Ismail et al. (2010). Transformational and Transactional Leadership Styles as A predictor of Individual Outcomes. Theoretical and Applied Economics, 6(547), 89-104.

Ivancevich et al. (2008). Organizational Behavior and Management $\left(8^{\text {th }}\right.$ ed.). Boston, McGraw Hill Irwin.

Kalargyrou et al. (2012) Leadership Skills in Management. Education Academy of Educational Leadership Journal, 16(4), 39-63.

Kawar, T. I., (2012). The Impact of Leadership on Student Learning. International Journal of Business and Social Science, 3(8), 319-322.

Kreitner, R., \& Kinicki, A. (2010). Organizational Behavior ( $9^{\text {th }}$ ed.). Boston, McGraw Hill Irwin.

Landis, \& Eric, A. (2011). $21^{\text {st }}$ Century Leadership Issues as They Pertain to a Small Private Liberal Arts University. Journal of Management Policy and Practice, 12(3), 108-111.

Lizzio et al. (2010). Pathways to Formal and Informal Student Leadership: The Influence of Peer and Teacher Student Relationships and Level of School Identification on Students' Motivations. International Journal of Leadership in Education, 14(1). 85-102. http://dx.doi.org/10.1080/13603124.2010.482674

Marie, K. F. (2008). The Impact of Transformational and Transactional Leadership on the Performance of the 
Human Resources in the Jordanian Pharmaceutical Manufacturing Companies. Unpublished Doctoral Dissertation. Amman Arab University for Graduate Studies. Jordan.

Osiemo, L. B. (2012). Developing Responsible Leaders: The University at the Service of the Person. Journal of Business Ethics, 108, 131-143. http://dx.doi.org/10.1007/s10551-011-1087-3

Randall, L. M. (2012). Transforming a University: A Study of Process Leadership. Academy of Educational Leadership Journal, 16(2), 1-20.

Raus, Alina, Haita, \& Mihaela. (2011). Leadership Style, Organizational Culture and Work Motivation. Managerial Challenges of the Contemporary Society, 2, 256-260.

Richmond, G., \& Manokore, V. (2010). Identifying Elements Critical for Functional and Sustainable Professional Learning Communities. Wiley Periodicals, Inc. November.

Robbins, S. P., \& Coulter, M. (2009). Management (10 ${ }^{\text {th }}$ ed.). Pearson Prentice Hall.

Rue, L. W., \& Byars, L. L. (2007). Management: Skills \& Application (12 ${ }^{\text {th }}$ ed.). Boston McGraw Hill Irwin.

Saadi etal. (2009). Democratic and Distributed Leadership for School Improvement: Case Studies from Pakistan. International Journal of Learning, 16(2), 521-532.

Sekaran, U. (2004). Research Methods for Business: A Skill-Building Approach (4 ${ }^{\text {th }}$ ed.). Singapore: John Wiley $\&$ Sons, Inc.

Singh, C. N. (2011). Human Resource Management. New Delhi, University Science Press.

Tahseen, N. (2010). The Relationship Between Principal's Leadership Style and Teacher Occupational Stress. Journal of Research and Reflections in Education, 4(2), 107-125.

Timothy, C. etal. (2011). Effects of Leadership Style on Organizational Performance: A Survey of Selected Small Scall Enterprises in Ikos-Ketu Council Development Area of Lagos State, Nigeria Australian. Journal of Business and Management Research, 1(7), 100-111.

Valenti, A. (2010). Five Essential Qualities of Leadership. Retrieved from http://www.leader-values.com/Content/. Cited on 1/8/2012

Voegtlin et al. (2012). Responsible Leadership in Global Business: A New Approach to Leadership and Its Multi-Level Outcomes. Journal of Business Ethics, 105, 1-16. http://dx.doi.org/10.1007/s10551-011-0952-4

Yukl, G. (2006). Leadership in Organizations ( $8^{\text {th }}$ ed.). New Jersey, Pearson Prentice Hall. 